\title{
KAJIAN TRANSITIVITAS TEKS TERJEMAHAN TAKEPAN SERAT MENAK YUNAN DAN KONTRIBUSINYA TERHADAP MATERI PEMBELAJARAN BAHASA INDONESIA BERBASIS TEKS DI SMP: ANALISIS BERDASARKAN LINGUISTIK FUNGSIONAL SISTEMIK
}

\author{
Muksin \\ Universitas Mataram \\ citraasa69@gmail.com
}

\begin{abstract}
Abstrak
Penelitian ini mendeskripsikan: (1) tipe proses transitivitas dalam teks terjemahan TSMY;. (2) tipe proses transitivitas yang mendominasi dalam TSMY; dan (3) kontribusi TSMY pada materi pembelajaran bahasa Indonesia berbasis teks di SMP.Penelitian ini menggunakan pendekatan Linguistik Fungsional Sistemik (LFS) dengan pengumpulan data menggunakan metode pustaka dan wawancara. Data dianalisis dengan mengkombinasikan metode kualitatif dan kuantitatif (mixedmethods). Analisis data dan pembahasan menyimpulkan tiga hal, yaitu: (1) Tipe proses transitivitas dalam TSMY meliputi: proses material, mental, tingkah laku, relasional, verbal, dan ekstensial. Sirkumstan dalam TSMY meliputi sirkumstan rentang, lokasi, sebab, lingkungan, penyerta, peran, masalah, pandangan, cara, dan kualitas; (2) Tipe proses transitivitas yang mendominasi dalam TSMY adalah proses material yang berjumlah $127(36,10 \%)$. Hal ini dapat diinterpretasikan bahwa TSMY lebih condong menggunakan kata-kata yang mengisyaratkan adanya tindakan, kegiatan, dan aktivitas fisik pelibat teks (partisipan). Tipe proses lainnya yang mendominasi adalah proses verbal yang berarti bahwa aktivitas fisik maupun mental selalu didahului dengan informasi dan dialog antarsemua elemen sehingga roda pemerintahan berjalan dengan baik; (3) hasil penelitian terhadap TSMY berkontribusi positif pada materi pembelajaran bahasa Indonesia berbasis teks di SMP, yakni dapat digunakan sebagai bahan ajar terutama yang terkait dengan teks.
\end{abstract}

Kata kunci: transitivitas; Takepan Serat Menak Yunan (TSMY); linguistik fungsional sistemik (LFS)

\begin{abstract}
The aim of this research is 1) to describe the types of transitivity process that is used in translation text TSMY, 2) to describe the types of transitivity process that is dominant employed in translation text TSMY, 3) to describe the contribution of text translation TSMY on the material of text based Indonesia language learning in SMP. This research used twoforms of approaching, they are as follow research approaching and analitycal approaching. Research approaching could be form systematic fungional linguistic analytical. The method of collecting data can be applied through pustaka method and interview. The method of data analitycal can be applied by using quantitative and qualitative method. Based on the result of data analitycal shows that representation of eksperiential meaning that is done by transitivity system particularly, element process is dominated by material process as much 127 or 36,105\%, white verbal process as moch 74 or $21,02 \%$, mental process as much 56 or $15,90 \%$, manifestation process as much 38 ooor 10,79\%, relational process as much 34 or 9,66\%.Then, attitude process as much 23 or 6,53\%. Futhermore the contribution of this result research toward material of text based Indonesia language learning in SMP (Junior high school) can be appliyed as material of narrative text in grad VIII.
\end{abstract}

Keywords: Tekxt transitivity; Takepan Serat Menak Yunan (TSMY); systematic; fungsional linguistiC

\section{PENDAHULUAN}

Penggunaan bahasa dalam realitas

sosial masyarakat suku Sasak pada masa lampau, terutama cerita-cerita yang terkait langsung dengan kalangan istana banyak terdokumentasi pada naskah-naskah kuno yang disebut takepan, seperti takepan Babat Peraya, Babat Selaparang, Banyu Hurung, Kenceli, Serat Menak Yunan,Puspa Karma, dan lain-lain. Bahasa yang digunakan dalam takepan ini merupakan salah satu 
wujud dari metafungsi bahasa, yaitu pengalaman nonlinguistik yang dipaparkan menjadi pengalaman linguistik.

Salah satu naskah lama yang penting untuk dikaji sistem bahasa dan fungsinya menggunakan teori Linguistik Fungsional Sistemik (LFS) adalah Takepan Serat Menak Yunan (TSMY). Naskah ini penting untuk dikaji karena berisi cerita-cerita seputar kehidupan kalangan istana (keluarga kerajaan) yang menjadi barometer pengembangan dan pelaksanaan nilai-nilai budaya saat itu. Hal itu berarti di dalamnya terkandung nilai-nilai budaya luhur yang semestinya dipahami dan dihayati untuk diimplementasikan dalam kehidupan bermasyarakat. Sebagai contoh Raja bersabda dengan lemah lembut. Pada klausa tersebut terdapat unsur proses verbal, yaitu bersabda, partisipan raja sebagai pembicara, dan dengan lemah lembut sebagai sirkumstan cara. Munculnya sirkumstan cara lemah lembut yang diucapkan oleh partispan raja kepada rakyatnya menunjukkan bahwa sejak zaman dahulu bangsa Indonesia sudah menjunjung tinggi etika dalam berkomunikasi. Artinya berkata dengan baik dan santun harus dilakukan oleh semua orang dan kepada semua orang, baik oleh atasan ke bawahan atau sebaliknya.

Pada penelitian ini, peneliti menganalisis teks TSMY yang sudah diterjemahkan ke dalam bahasa Indonesia yang diterjemahkan oleh Lalu Rabdi yang berasal dari dusun Padamara, desa Padamara, kecamatan Sukamulia, Lombok Timur dengan menitikberatkan pada analisis sistem transitivitas. Digunakannya kajian sistem transitivitas berdasarkan teori LFS karena teori ini sangat sesuai untuk menganalisis teks takepan yang di dalamnya terdapat klausa-klausa yang mengandung prosesproses, seperti proses material, proses mental, proses relasional, proses tingkah laku, proses verbal, dan proses wujud. Atas dasar asumsi teoretis ini, penting untuk dilakukan kajian terhadap TSMY dengan menggunakan teori atau pendekatan LFS yang hasilnya dapat memberikan kontribusi pada materi pembelajaran bahasa Indonesia berbasis teks di SMP.

Permasalahan yang dikaji dalam penelitian ini meliputi: (1) tipe proses transitivitas yang terdapat dalam teks terjemahan TSMY; (2) tipe proses transitivitas yang mendominasi dalam teks terjemahan TSMY; dan (3) kontribusi teks terjemahan TSMY pada materi pembelajaran bahasa Indonesia berbasis teks di SMP.

Dalam penelitian ini pengumpulan data dilakukan dengan menggunakan metode pustaka dan wawancara.Metode pustaka dipergunakan guna pengumpulkan seluruh teks yang berupa bait-bait puisi lama (tembang) yang terdapat di dalam TSMY. Metode wawancara digunakan untuk mengumpulkan data pendukung dari informan. Wawancara dilakukan langsung oleh peneliti untuk mendapatkan data-data akurat terkait dengan TSMY. Penggunaan metode wawancara dalam penelitian ini didasarkan atas dua alasan. Pertama, 
dengan wawancara, peneliti dapat menggali tidak sekedar apa yang diketahui pada objek penelitian tetapi juga apa yang tersembunyi di dalam objek penelitian tersebut. Kedua, apa yang ditanyakan pada informan bisa mencakup hal-hal yang bersifat lintas waktu, yang berkaitan dengan masa lampau, kini, dan yang akan datang. Data dianalisis dengan metode kombinasi (mixedmethods), yakni mengkombinasikan antara metode kualitatif dan metode kuntitatif. Metode kualitatif dipergunakan untuk melakukan kategorisasi dan pemolaan tipe proses transitivitas teks terjemahan yang terdapat dalam TSMY, sedangkan metode kuantitatif dipergunakan untuk mendeskripsikan perhitungan persentase setiap tipe proses transitivitas guna mendukung analisis kualitatif. Dengan demikian, diperoleh gambaran yang jelas tentang bentuk dan pola serta persentase transitivitas dalam teks terjemahan TSMY.

\section{KONSEP DAN KERANGKA TEORI}

Dalam kitannya dengan artikel ini, terdapat istilah-istilah yang merupakan kata kunci yang perlu diuraikan batasan dan konsep dasarnya. Istilah-istilah tersebut antara lain, teks, transitivitas, dan pembelajaran. Teks adalah unit tata bahasa tulis yang berwujud kata, frasa, dan klausa yang terdapat dalam TSMY yang saling berhubungan membentuk suatu makna yang lengkap. Transitivitas adalah realisasi paparan pengarang dalam TSMY berupa klausaklausa yang terdiri atas proses, partisipan, dan sirkumstan sebagai pengalaman kehidupan manusia yang berbentuk ragam pengalaman linguistik. Pembelajaran adalah suatu kegiatan berupa proses interaksi antara pendidik dan peserta didik dengan bahan belajar berupa TSMY untuk memperkaya pengetahuan teks wacana.

Linguistik Fungsional Sistemik (LFS) merupakan teori bahasa yang bertitik pada fungsi dan penggunaan bahasa, yaitu: (1) bahasa adalah fungsional (language is funncional), (2) bahasa adalah membuat maknamakna (the funcional is language is to make meanings) dan (3) penggunaan bahasa adalah kontekstual (language use is contextual) (Silvana, 2003). Pada tataran konteks, penyerta teks dari dalam dan luar terbentuk atas tiga komponen utama, yaitu; 1) apa yang dibicarakan (field), siapa yang berbicara dan dibicarakan (tenor), dan bagaimana dibicarakan (mode). Konteks dalam LFS juga terbagi dalam beberapa aspek lainnya, seperti; konteks budaya yang terkait batasan, tahapan, dan tujuan yang dicapai dalam interaksi sosial dan konteks ideologi yang dimuat tentang konstruksi atau konsepsosial tentang keharusan dan ketidakharusan dalam penetapan perbuatan dilakukan dalam interaksi sosial. Kedua konteks ini dibentuk sebagai perwujudan pandangan terhadap realitas sosial. Teks tersebut diproduksi dalam konteks sosial yang melatarbelakangi kegiatan-kegiatan yang dilakukan oleh manusia, baik konteks situasi maupun konteks budaya. Mahsun (2013:1) mendefinisikan teks sebagai satu- 
an bahasa yang digunakan sebagai ungkapan suatu kegiatan sosial baik secara lisan maupun tulis dengan struktur berpikir lengkap.

Dalam setiap interaksi antarpemakai bahasa, penutur menggunakan bahasa untuk memapar, mempertukarkan, dan merangkai atau mengorganisasikan pengalaman. Dengan ketiga fungsi bahasa dalam kehidupan manusia, bahasa sekaligus disebut berfungsi tiga dalam komunikasi, yakni memapar, mempertukarkan, dan merangkai pengalaman yang secara teknis masingmasing disebut ideational function, interpersonal function, dan textual function (Halliday, 1994: xiii; Eggins, 2004:3). Sejalan dengan ketiga fungsi itu, bahasa dikatakan membawa tiga makna, yakni makna pengalaman (ideational meaning), makna antarpersona atau makna pertukaran (interpersonal meaning), dan makna perangkaian atau pengorganisasian (textual meaning).

Makna ideasional direalisasikan melalui sistem transitivitas. Sistem transitivitas menyebabkan manusia menggambarkan mental dan fakta untuk mengetahui kejadian eksternal dan internal yang dijadikan pengalaman untuk menciptakan bentuk-bentuk proses. Pengalaman ini merupakan proses yang sedang terjadi. Ketika seseorang merealisasikan pengalamannya menjadi pengalaman linguistik, maka terbentuklah representasi pengalaman linguistik itu dan menjadi komoditas yang ditransaksikan oleh pemakai bahasa. Realisasi pengalaman linguistik pemakai bahasa itu disebut transitivitas. Pengalaman yang sempurna direalisasikan oleh tiga unsur penting, yaitu proses, partisipan, dan sirkumstan.

Proses menurut Saragih (2006:24, 2013:9) merupakan aktivitas yang terjadi dalam klausa yang menurut tata bahasa tradisional dan formal disebut verba. Proses dapat dikatakan sebagai kegiatan ataupun aktivitas yang terjadi dalam kata kerja. Proses merupakan inti dari suatu pengalaman. Menurut Halliday (Saragih, 2006:25 dan Sinar, 2012:30) pengalaman penutur bahasa diwujudkan melalui enam jenis proses yang menentukan jenis pengalaman itu, yang meliputi tiga pengalaman utama (primary process), yang terdiri atas proses material, proses mental, dan proses relasional; dan tiga pengalaman pelengkap (secondary process), yang terdiri atas proses tingkah laku, proses verbal, dan proses wujud sebagaimana tergambar dalam skema berikut.

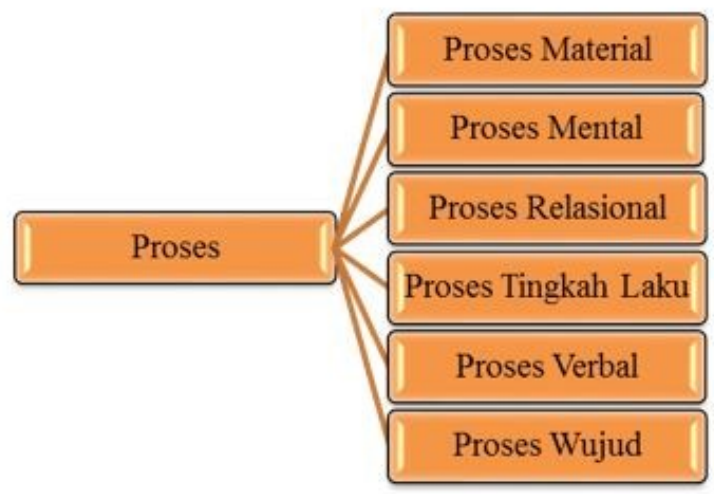

Proses material dapat didefinisikan sebagai proses atau kegiatan yang menyangkut fisik, yakni dapat diamati dengan menggunakan indra. Batasan ini mengandung arti bahwa setiap proses bisa 
diikuti oleh aspek sedang, seperti Saya sedang mencuci dan Dita sedang memasak di dapur. Beberapa kata kerja atau verba yang termasuk proses material antara lain: berjalan, bekerja, berlari, membaca, melompat, berkumpul, bergabung, menulis, membaca, berenang, bertinju, bersepeda, berbaring, memukul, dan meletus. Menurut Saragih (2006:26) dan Sinar (2012:61, 2012:30), partisipan yang terlibat dalam satu proses material dilabeli pelaku (actor) dan gol (goal) dengan rincian pelaku sebagai sumber atau pembuat aktivitas (partisipan I) dan gol sebagai wujud yang kepadanya proses ditujukan atau yang dikenai proses (partisipan II).

Proses mental didefinisikan sebagai suatu proses yang menyangkut kognisi, emosi, dan persepsi yang terjadi dalam diri manusia sendiri, misalnya melihat, merasa, mendengar, mencintai, percaya, membenci, dan sebagainya (Saragih, 2006:27). Proses ini terjadi di dalam diri manusia dan mengenai mental kehidupan. Secara semantik, proses mental menyangkut pelaku manusia saja ataupun makhluk lain yang dianggap berperilaku seperti manusia. Perbedaan proses mental dan material yang mencakup kriteria semantik dan sintaksis adalah sebagai berikut: (a) proses mental menyangkut manusia, (b) proses mental dapat diikuti proyeksi, sedangkan proses material tidak dapat, (c) proses mental tidak dapat diikuti oleh aspek sedang, (d) proses mental merupakan proses dua hal saja, sedangkan klausa material satu hala sa-
ja.Saragih (2006:29) menegaskan bahwa partisipan yang terlibat dalam proses mental disebut pengindera (senser) sebagai partisipan I dan partisipan II yang dikenai proses dilabeli fenomenon (phenomenon).

Proses relasional berfungsi menghubungkan satu entitas dengan wujud atau lingkungan lain di dalam hubungan intensif, sirkumstan, atau kepemilikan dan dengan cara (mode) identifikasi atau atribut. (Saragih, 2006:29).Kata kerja yang dapat dikategorikan ke dalam proses ini seperti; menjadi, merupakan, kelihatan, berharga, bernilai, kedengaran, terdengar, menunjukkan, menandakan, memainkan, mempunyai, memiliki, dll. Senada dengan Saragih, Sinar (2012:63, 2012:33) mengemukakan bahwa proses relasional adalah proses penghubung, penyandang penciri atau penanda "being" yang maksudnya sesuatu dianggap memiliki atribut atau penanda identitas. Selanjutnya, Sinar menjelaskan bahwa proses relasional dibagi atas tiga jenis, yakni: (1) intensif, (2) sirkumstan, dan (3) posesif. Setiap jenis mempunyai dua sarana: (a) atributif, dan (b) identifikasi, sehingga pengembangannya dapat menjadi enam jenis proses relasional, yaitu: (1) proses: relasional: intensif: identifikasi, (2) proses: relasional: intensif: atribut, (3) proses: relasional: sirkumstan: identifikasi, (4) proses: relasional: sirkumstan: atribut, (5) proses: relasional: kepemilikan: identifikasi, (6) proses: relasional: sirkumstan: atribut. 
"Satu proses relasional termasuk jenis identifikasi jika empat kriteria berikut ini terpenuhi, yaitu: (1) Bentuk dan Nilai membentuk hubungan identik atau sama dengan $(\mathrm{a}=\mathrm{b})$; (2) Bentuk dan Nilai dapat dipertukarkan (posisi keduanya); (3) Kata adalah dapat diletakkan antara Bentuk dan Nilai, dan klausa bermakna Bentuk = Nilai; dan (4) Perpindahan tempat Bentuk ke Nilai menbentuk kalimat pasif." (Sragih, 2006:44).

Proses tingkah laku (behavioural) didefinisikan sebagai aktivitas atau kegiatan fisiologis yang menyatakan tingkah laku fisik manusia (Saragih, 2006:33). Secara semantik, kategori proses tingkah laku terletak antara proses material dan mental. Implikasinya adalah sebagai proses tingkah laku memiliki sifat proses material dan sebagian lagi memiliki proses mental. Dalam hal ini yang dapat dikategorikan pada proses ini, misalnya kata kerja bernapas, menguap, tertawa, sendawa, tidur, mengeluh, menggerutu dan lain sebagainya.

Proses verbal adalah proses yang menunjukkan aktivitas atau kegiatan yang menyangkut informasi. Proses verbal berada antara proses mental dan relasional. Jadi, proses verbal sebagian memiliki ciri proses mental dan sebagian lagi memiliki ciri proses relasional. Adapun yang dapat dikategorikan dalam proses ini antara lain: kata kerja memerintah, meminta, menjelaskan, mengatakan, menerangkan, mengkritik, menguji, memberitahu, menegaskan, menekankan, berseru, berjanji, bersumpah, dan lain sebagainya.

Menurut Saragih (2006:35, 2013:12) dan Sinar (2007:66, 2012:35) proses wujud (eksistensial) menunjukkan keberadaan satu entitas. Secara semantik, proses wujud terjadi antara proses material dan proses relasional. Dengan demikian, proses wujud di satu sisi memiliki ciri proses material dan di sisi lain memiliki ciri proses relasional. Proses wujud adalah suatu proses yang mengekspresikan keberadaan suatu benda tempat benda itu memang nyata atau memang benar-benar ada. "Proses eksistensial merupakan proses yang menunjukkan adanya sesuatu. Ada beberapa kata yang dapat dikategorikan ke dalam proses wujud, misalnya ada, berada, bertahan, muncul, tejadi, bersebar, tumbuh, dan lain-lain.

Dalam klausa dapat ditemukan satu atau dua partisipan sehingga muncul partisipan I dan II. Yang dimaksud dengan Partisipan I adalah Partisipan yang melakukan atau melaksanakan aktivitas atau Proses dan Partisipan II adalah Partisipan yang kepadanya aktivitas atau Proses ditujukan (Saragih, 2013:70). Adapun rincian partisipan I dan partisipan II pada semua jenis proses sebagai berikut.

\begin{tabular}{|l|l|l|}
\hline $\begin{array}{c}\text { Jenis Pros- } \\
\text { es }\end{array}$ & \multicolumn{1}{|c|}{ Partisipan I } & Partisipan II \\
\hline Material & Pelaku & Gol \\
\hline Mental & Pengindera & Fenomena \\
\hline Relasional & $\begin{array}{l}\text { Identifikasi Bentuk } \\
\text { Atribut: Penyandang } \\
\text { Keemilikan : Milik }\end{array}$ & $\begin{array}{l}\text { Nilai,Atribut } \\
\text { Milik }\end{array}$ \\
\hline $\begin{array}{l}\text { Tingkah } \\
\text { Laku }\end{array}$ & Petingkah Laku & - \\
\hline Verbal & Pembicara & Perkataan \\
\hline Wujud & Maujud & - \\
\hline
\end{tabular}


Sirkumstan dapat didefinisikan sebagai lingkungan, sifat, atau lokasi tempat berlangsungnya suatu proses. Sirkumstan berada di luar jangkauan proses. Oleh karena itu, sirkumstan berlaku dalam semua jenis proses. Sirkumstan dapat disetarakan dengan keterangan yang lazim digunakan dalam tata bahasa tradisional. (Saragih, 2006:38, 2013:17). Menurut Halliday (dalam Sinar, 2012:69, 2012:38) dan Saragih (2006:38, 2013:17-18), sirkumstan terdiri atas (1) rentang, (2) lokasi, (3) cara, (4) sebab, (5) lingkungan, (6) masalah, (7) peran, (8) penyerta, dan (9) pandangan.

Sirkumstan rentang berkaitan dengan waktu dan tempat. Sirkumstan ini dapat diidentifikasi dengan kalimat pertanyaan "berapa lamanya?" dan "berapa jauhnya?"Sirkumstan lokasi berkaitan dengan waktu dan tempat. Cara mengidentifikasi sirkumstan ini yaitu dengan mengajukan kalimat pertanyaan "kapan?" dan “di mana?"Sirkumstan cara berkaitan dengan apa ia melakukan sesuatu dengan cara mengidentifikasi kalimat pertanyaan "bagaimana?" Sirkumstan sebab berkaitan dengan sebab atau latar belakang terjadinya sesuatu. Hal ini bisa diidentifikasi dengan kalimat pertanyaan “mengapa?" Sirkumstan penyerta berkaitan dengan keikutsertaan seseorang dalam melaksanakan sesuatu. Dalam hal ini dapat diidentifikasi dengan pertanyaan "dengan siapa?"Sirkumstan masalah berkaitan dengan masalah yang dibicarakan. Hal ini dapat diidentifikasi dengan kalimat pertanyaan "tentang apa?"

Konteks adalah sesuatu yang menyertai atau yang bersama teks. Egins (2004:86) berpandangan bahwa teks tidak dapat ditafsirkan sama sekali kecuali dengan mengacu pada konteks. Senada dengan itu, Halliday \& Hasan, (1992:13) berpandangan bahwa teks adalah bahasa yang sedang melaksanakan tugas tertentu dalam konteks situasi. Gie (2011:100) juga mengungkapkan hal yang senada dengan itu bahwa konteks merupakan gagasan penting dalam memahami bahasa yang digunakan dalam teks. Kedua-duanya memlilki hubungan yang sangat erat. "Hubungan mendasar antara keduanya adalah bahasa harus dipelajari dalam konteks budaya dan budaya dapat dipelajari melalui bahasa." (Sukri dan Rusdiawan, 2008:49). Makna yang terealisasi dalam teks merupakan hasil interaksi pemakai bahasa dengan konteksnya, sehingga konteks merupakan wacana terbentuknya teks.

\section{PEMBAHASAN}

Dalam pembahasan artikel ini disajikan hasil dan pembahasan terhadap masingmasing hasil penelitian yang telah dilakukan. Hasil dan pembahasan disajikan secara hierarkis berdasarkan urutan rumusan masalah dan tujuan penelitian. Hierarkis penyajian yang dimaksud sebagai berikut (1) data tentang tipe proses dalam TSMY; (2) data tentang jumlah dan persentase kemunculan masing-masing tipe proses dalam TSMY; (3) deskripsi kontribusi hasil 
penelitian terhadap pembelajaran bahasa Indonesia berbasis teks di SMP.

\section{Tipe Proses Transitivitas TSMY}

Sistem Transitivitas dalam TSMY berkaitan erat dengan dimensi medan teks yang ada di dalamnya. Setiap medan teks berpusat pada unsur proses sehingga proses merupakan bagian utama dalam transitivitas. Setiap proses diapit oleh partisipan atau setara dengan subjek atau objek dan sirkumstan yang setara dengan keterangan. Dalam TSMY ditemukan enam jenis proses, yaitu proses material, mental, tingkah laku, relasional, verbal, dan ekstensial. Sir- kumstan yang ditemukan adalah sirkumstan rentang, sirkumstan lokasi, sirkumstan cara, sirkumstan penyerta, dan sirkumstan pandangan.

Proses material adalah sebuah proses yang terdapat dalam bagian sistem transitivitas yang menjelaskan suatu proses melakukan suatu aktivitas. Pada umumnya dalam proses material muncul dua partisipan, yakni partisipan I disebut actor dan partisipan II disebut goal. Kedua partisipan ini direalisasikan menggunakan kata benda. Berikut ini contoh proses material.

1) Di pagi hari raja tersebut menggunakan pakaian yang berkilat kemilau (Sinom 3 bait ke-6)

\begin{tabular}{|c|c|c|c|c|}
\hline Di pagi hari & raja tersebut & menggunakan & $\begin{array}{c}\text { Pakaian yang } \\
\text { berkilat kemilau }\end{array}$ & \\
\hline $\begin{array}{c}\text { Sirkumstan: } \\
\text { Rentang }\end{array}$ & $\begin{array}{c}\text { PartisipanI: } \\
\text { Pelaku }\end{array}$ & $\begin{array}{c}\text { Pros- } \\
\text { es :Material }\end{array}$ & $\begin{array}{c}\text { PartisipanII: } \\
\text { Gol }\end{array}$ & $\begin{array}{c}\text { Label } \\
\text { fungsi }\end{array}$ \\
\hline $\begin{array}{c}\text { grup adver- } \\
\text { bia }\end{array}$ & $\begin{array}{c}\text { grup nomi- } \\
\text { na }\end{array}$ & grup verba & grup nomina & $\begin{array}{c}\text { Label ke- } \\
\text { las }\end{array}$ \\
\hline
\end{tabular}

Pada klausa pertama, proses diapit oleh dua partisipan, yaitu Raja tersebut sebagai partisipan I dan pakaian yang berkilat kemilau sebagai partisipan II. Raja tersebut dalah partisipan yang mengerjakan suatu kegiatan, yaitu menggunakan, sedangkan pakaian yang berkilat kemilau sebagai partisipan kepada siapa perbuatan itu ditujukan dinamakan sebagai Gol.

2) Karun menunjukkan surat (sinom 80 bait ke 28)

\begin{tabular}{|c|c|c|c|}
\hline Karun & menunjukkan & Surat & \\
\hline $\begin{array}{c}\text { PartisipanI: } \\
\text { Pelaku }\end{array}$ & Proses material & PartisipanII: Gol & $\begin{array}{c}\text { Label } \\
\text { fungsi }\end{array}$ \\
\hline grup nomina & grup verba & grup nomina & label kelas \\
\hline
\end{tabular}

Seperti halnya klausa pertama, pada klausa kedua prosesnya diapit oleh dua partisipan, yaitu Karun sebagai partisipan I dan surat sebagai partisipan II. Karun adalah partisipan yang mengerjakan suatu kegiatan, yaitu menunjukkan, sedangkan surat sebagai partisipan kepada siapa perbuatan itu ditujukan dinamakan sebagai Gol 
3) Ikan belah berenang paling depan (Pangkur 22 bait ke-9)

\begin{tabular}{|c|c|c|c|}
\hline Ikan belah & berenang & paling depan & \\
\hline Pelaku & Proses: material & Sirkumstan: lokasi & Label Fungsi \\
\hline grup nomina & grup verba & grupadverbial & Label Kelas \\
\hline
\end{tabular}

Pada klausa ketiga proses berenang hanya diapit oleh satu partisipan dan sirkumstan. Ikan belah merupakan pelaku yang melakukan kegiatan berenang yang diikuti oleh sirkumstan lokasi, yaitu di mana posisi ikan belah itu berada. Dengan demikian, ketiga klausa di atas merupakan klausa yang menunjukkan pelaku melakukan kegiatan atau aksi.

Proses mental merupakan proses yang

1) Beliau sangat disayangi rakyatnya (sinom 2 bait ke-5)

\begin{tabular}{|c|c|c|c|}
\hline Beliau & sangat disayangi & Rakyatnya & \\
\hline Pengindra & Proses:Mental & $\begin{array}{c}\text { PartisipanII:Fenomen } \\
\text { on }\end{array}$ & Label fungsi \\
\hline $\begin{array}{c}\text { grup nomi- } \\
\text { na }\end{array}$ & grup verba & grup nomina & Label kelas \\
\hline
\end{tabular}

Klausa pertama di atas merupakan klausa yang berproses mental keinginan karena berhubungan dengan perasaan atau hati. Hal itu ditunjukkan oleh kata sangat disayangi sebagai wujud penggambaran keinginan

2) Raja Nursiwan Sangat menyayangi para menteri (sinom 22 bait ke-11)

\begin{tabular}{|c|c|c|c|}
\hline Raja Nursiwan & sangat menyayangi & para menteri & \\
\hline Pengindra & Proses: Mental & Fenomenon & Label fungsi \\
\hline grup nomina & grup verba & grup nomina & label kelas \\
\hline
\end{tabular}

Seperti halnya klausa pertama di atas, klausa kedua juga merupakan klausa yang berproses mental keinginan karena berhubungan dengan perasaan atau hati, yang dalam ditunjukkan dengan kata sangat menyayangi sebagai wujud penggambaran keingi- subjek (partisipan I) yaitu kata beliau. Pada klausa di atas juga terdapat partisipan II yang disebut fenomena yaitu kata rakyatnya sebagai objek keinginan partisipan I. menghadirkan partisipan manusia atau mirip manusia atau lainnya yang dapat melakukan proses mengindra (perseptif), berpikir (kognitif), dan merasa (afektif). Partisipan proses mental ada dua, yaitu pengindra (senser) dan fenomena (phenomenon). Berikut ini contoh penganalisisan klausa dengan proses mental. 
3) Dia sangat dicintai oleh Jayeng Rane (pangkur 33 bait ke- 13)

\begin{tabular}{|c|c|c|c|}
\hline Dia & sangat dicintai & oleh Jayeng Rane & \\
\hline Fenomenon & Proses: mental & Pengindra & Label Fungsi \\
\hline grup pronomina & grup adverbia & grup nomina & Label Kelas \\
\hline
\end{tabular}

Contoh klausa ketiga di atas merupakan klausa yang berproses mental keinginan karena berhubungan dengan perasaan atau hati, yang ditunjukkan dengan kata sangat dicintai sebagai wujud penggambaran keinginan subjek (partisipan I) yaitu kata Jayengrane. Antara klausa pertama dan ketiga dengan klausa kedua terlihat ada perbedaan sedikit, yaitu kalau pada klausa pertama dan ketiga, partisipan II yang disebut phenomenon menggunakan kata ganti orang, sedangkan pada klausa kedua menunjuk ke orangnya langsung, yaitu raja Nursiwan yang merupakan objek keinginan partisipan I.
Proses relasional berfungsi menghubungkan satu entitas dengan lingkungan lain di dalam hubungan intensif, sirkumstan, atau kepemilikan dan dengan cara (mode) identifikasi atau atribut. Hubungan ini bisa bersifat memberikan nilai terhadap partisipan I. Partisipan dalam proses relasional atributif ialah carrier dan attribute.Satu proses dapat berfungsi sebagai proses material atau relasional. Satu proses adalah relasional jika proses itu menunjukkan relasi atau hubungan dalam satu konteks pemakaian bahasa. Berikut ini contoh proses relasional.

1) Izinkan saya melawan dia (Sinom 37 bait ke-15)

\begin{tabular}{|c|c|c|c|c|}
\hline Izinkan & saya & Melawan & dia & \\
\hline $\begin{array}{c}\text { Sirkumstan } \\
\text { masalah }\end{array}$ & $\begin{array}{c}\text { PartisipanI: } \\
\text { Tanda }\end{array}$ & $\begin{array}{c}\text { Pros- } \\
\text { es:Relasional: } \\
\text { Identifikasi }\end{array}$ & $\begin{array}{c}\text { PartisipanI } \\
\text { I: Nilai }\end{array}$ & $\begin{array}{c}\text { Label } \\
\text { fungsi }\end{array}$ \\
\hline $\begin{array}{c}\text { grup adver- } \\
\text { bia }\end{array}$ & grup nomina & grup verba & $\begin{array}{c}\text { grup nomi- } \\
\text { na }\end{array}$ & label kelas \\
\hline
\end{tabular}

Klausa pertama di atas merupakan klausa relasional identifikasi. Dikatakan klausa proses relasional identifikasi karena prosesnya dapat diganti dengan menjadi, bentuk dan nilai dapat dipertukarkan po- sisinya, perpindahan tempat bentuk ke nilai membentuk kalimat pasif. Perubahannya seperti klausa berikut ini. Izinkan saya menjadi dia dan Izinkan saya dilawan dia

2) Airnya kelihatan biru menyeramkan (Pangkur 2 bait ke-1)

\begin{tabular}{|c|c|c|c|}
\hline Airnya & kelihatan & $\begin{array}{c}\text { biru me- } \\
\text { nyeramkan }\end{array}$ & \\
\hline $\begin{array}{c}\text { Partisipan I: } \\
\text { atribut: penyan- } \\
\text { dang }\end{array}$ & $\begin{array}{c}\text { Proses: relasional } \\
\text { atribut }\end{array}$ & $\begin{array}{c}\text { PartisipanII: } \\
\text { atribut }\end{array}$ & $\begin{array}{c}\text { Label } \\
\text { Fungsi }\end{array}$ \\
\hline grup nomina & grup verba & grup adjektif & $\begin{array}{c}\text { Label Ke- } \\
\text { las }\end{array}$ \\
\hline
\end{tabular}


Pada klausa kedua, Prosesnya samasama bisa bertukar posisi, namun hasil pertukaran tersebut tidak bisa membentuk kalimat pasif sehingga klausa kedua tidak bisa dikategorikan ke dalam proses relasional identifikasi, tetapi masuk ke dalam kategori proses relasional atribut.

3) Sekarang hati Jayeng Rane menjadi gembira (Pangkur 44 bait ke-9)

\begin{tabular}{|c|c|c|c|c|}
\hline Sekarang & $\begin{array}{c}\text { hati Jayeng } \\
\text { Rane }\end{array}$ & Menjadi & gembira & \\
\hline $\begin{array}{c}\text { Sirkumstan: } \\
\text { lokasi: waktu }\end{array}$ & $\begin{array}{c}\text { Partisipan I: } \\
\text { atribut: pen- } \\
\text { yandang }\end{array}$ & $\begin{array}{c}\text { Proses: } \\
\text { relasional } \\
\text { atribut }\end{array}$ & $\begin{array}{c}\text { PartisipanII: } \\
\text { atribut }\end{array}$ & $\begin{array}{c}\text { Label } \\
\text { Fungsi }\end{array}$ \\
\hline grup adverbial & $\begin{array}{c}\text { grup nomi- } \\
\text { na }\end{array}$ & grup verba & $\begin{array}{c}\text { grup adjek- } \\
\text { tiva }\end{array}$ & $\begin{array}{c}\text { Label Ke- } \\
\text { las }\end{array}$ \\
\hline
\end{tabular}

Klausa ketiga sama halnya dengan klausa kedua, yaitu prosesnya sama-sama bisa bertukar posisi, namun hasil pertukaran tersebut tidak bisa membentuk kalimat pasif sehingga klausa ketiga tidak bisa dikategorikan ke dalam proses relasional identifikasi, tetapi masuk ke kategori proses relasional atribut.

Proses tingkahlaku adalah perpaduan antara proses material dan proses mental. Proses ini mengekspresikan bentuk tindakan yang berhubungan dengan psikologi para pelibat teks. Sebagian besar proses perilaku hanya memiliki satu partisipan yang sifatnya wajib hadir dan dinamakan behaver. Berikut ini contoh klausa dengan proses tingkah laku.

1) Kemudian dia mohon pamit untuk memulai perjalanan (Sinom 65 bait ke-25)

\begin{tabular}{|c|c|c|c|c|}
\hline Kemudian & dia & mohon pamit & $\begin{array}{c}\text { untuk memu- } \\
\text { lai perjal- } \\
\text { anan }\end{array}$ & \\
\hline Penerus & $\begin{array}{c}\text { Partisipan: } \\
\text { Petingkah } \\
\text { laku }\end{array}$ & $\begin{array}{c}\text { Proses:Tingkah } \\
\text { laku }\end{array}$ & $\begin{array}{c}\text { Sirkumstan: } \\
\text { Lingkungan }\end{array}$ & $\begin{array}{c}\text { Label } \\
\text { fungsi }\end{array}$ \\
\hline & grup nomina & grup verba & $\begin{array}{c}\text { grup adver- } \\
\text { bia }\end{array}$ & label kelas \\
\hline
\end{tabular}

Pada contoh klausa proses tingkah laku di atas, klausanya hanya memiliki satu partisipan yang wajib hadir yang dinamakan behaver, yaitu kata dia. Ketidakhadiran partisipan dia, misalnya tentu akan membuat makna klausa itu menjadi tidak jelas.

Proses verbal berada antara proses mental dan relasional. Dengan demikian, proses verbal sebagian memiliki ciri proses mental dan sebagian lagi memiliki ciri proses relasional. Proses verbal biasanya terdiri atas tiga partisipan, yaitu sayer, receiver, dan verbiage. Sayer adalah yang bertanggungjawab atas terjadinya proses verbal itu. $R e$ ceiver merupakan symbol kepada siapa proses verbal itu ditujukan. Selanjutnya, verbiage adalah pernyataan yang dinominalisasikan oleh proses verbal. Proses verbal yang ditemukan dalam TSMY terlihat 
pada contoh berikut.

1)Patih Karun berkata "Wahai rajaku, hamba memberikan peringatan, kita ini belum bersedia menggempur raja Yunan.” (Sinom 39 bait ke-15)

\begin{tabular}{|c|c|c|c|}
\hline Patih Karun & berkata & $\begin{array}{l}\text { Wahai rajaku, hamba mem- } \\
\text { berikan peringatan, kita ini } \\
\text { belum bersedia menggempur } \\
\text { raja Yunan }\end{array}$ & Perkataan \\
\hline $\begin{array}{c}\text { PartisipanI: } \\
\text { Penyampai } \\
\text { pembicaraan }\end{array}$ & $\begin{array}{c}\text { Proses: } \\
\text { verbal }\end{array}$ & $\begin{array}{c}\text { Label } \\
\text { fungsi }\end{array}$ \\
\hline grup nomina & $\begin{array}{c}\text { grup ver- } \\
\text { ba }\end{array}$ & grupadverbial & label kelas \\
\hline
\end{tabular}

2)Aku berterus terang kepadamu (sinom 55 bait ke-21)

\begin{tabular}{|c|c|c|c|}
\hline Aku & berterus terang & kepadamu & \\
\hline $\begin{array}{c}\text { PartisipanI:Penyamp } \\
\text { ai pembicara }\end{array}$ & Proses:Verbal & Penerima & $\begin{array}{c}\text { Label } \\
\text { fungsi }\end{array}$ \\
\hline grup pronomina & grup verba & grup ronomina & label kelas \\
\hline
\end{tabular}

3) Kemudian Jayeng Rane mengeluarkan kata-kata dengan lembut (Pangkur 40 bait ke-7.)

\begin{tabular}{|c|c|c|c|c|c|}
\hline Kemudian & $\begin{array}{c}\text { Jayeng } \\
\text { Rane }\end{array}$ & $\begin{array}{c}\text { Menge- } \\
\text { luarkan }\end{array}$ & kata-kata & $\begin{array}{c}\text { dengan lem- } \\
\text { but }\end{array}$ & \\
\hline & Pembicara & $\begin{array}{c}\text { Proses: } \\
\text { verbal }\end{array}$ & perkataan & $\begin{array}{c}\text { Sirkumstan: } \\
\text { cara }\end{array}$ & $\begin{array}{c}\text { Label } \\
\text { Fungsi }\end{array}$ \\
\hline & $\begin{array}{c}\text { grup nom- } \\
\text { ina }\end{array}$ & grup verba & $\begin{array}{c}\text { grup nom- } \\
\text { ina }\end{array}$ & $\begin{array}{c}\text { grup adjek- } \\
\text { tiva }\end{array}$ & $\begin{array}{c}\text { Label } \\
\text { Kelas }\end{array}$ \\
\hline $\begin{array}{c}\text { Makna } \\
\text { logis: } \\
\text { waktu: } \\
\text { berurutan }\end{array}$ & & & & & \\
\hline
\end{tabular}

Pada ketiga contoh di atas, dalam setiap unit pengalaman linguistik terdapat masingmasing satu proses verbal, yaitu berkata, berterus terang, dan mengeluarkan. Proses verbal tersebut dapat berhubungan dengan dua partisipan. Pada kalausa [1 dan 3] proses diapit oleh partisipan I sebagai penyampai pembicara dan partisipan II sebagai perkataan. Pada klausa kedua [2] proses diapit oleh partisipan I sebagai penyampai pembicara dan partisipan II sebagai penerima perkataan, kemudian dilanjutkan dengan sirkumstan yang menerangkan bagaimana perkataan itu disampaikan oleh si penyampai pembicaraan.

Proses wujud merupakansuatu proses yang mengekspresikan keberadaan suatu benda bahwa benda itu memang nyata. Proses wujud hanya mengikat satu partisipan yaitu maujud. Contoh proses wujud yang ditemukan TS MY adalah sebagai berikut. 
1) Apakah ada masalahnya sehingga tak berkehendak datang (Sinom 25 bait ke-13)

\begin{tabular}{|c|l|c|c|c|}
\hline Apakah & Ada & Masalahnya & $\begin{array}{c}\text { sehingga tak berke- } \\
\text { hendak datang }\end{array}$ & \\
\hline & $\begin{array}{c}\text { Proses: } \\
\text { Wujud }\end{array}$ & $\begin{array}{c}\text { PartisipanI: } \\
\text { Maujud }\end{array}$ & Sirkumstan:Sebab & $\begin{array}{c}\text { Label } \\
\text { fuugsi }\end{array}$ \\
\hline $\begin{array}{c}\text { Pemarkah } \\
\text { pertan- } \\
\text { yaan }\end{array}$ & $\begin{array}{l}\text { grup } \\
\text { verba }\end{array}$ & $\begin{array}{c}\text { grup nomi- } \\
\text { na }\end{array}$ & grup adverbia & label kelas \\
\hline
\end{tabular}

2) Ada dua keponakannya sangat kuat dan perkasa (Sinom 41bait ke-16)

\begin{tabular}{|c|c|c|c|}
\hline Ada & $\begin{array}{c}\text { dua keponakann- } \\
\text { ya }\end{array}$ & $\begin{array}{c}\text { sangat kuat dan per- } \\
\text { kasa }\end{array}$ & \\
\hline $\begin{array}{c}\text { Proses: } \\
\text { Wujud }\end{array}$ & Maujud & $\begin{array}{c}\text { Sirkum- } \\
\text { stan:Pandangan }\end{array}$ & Label fungsi \\
\hline grup verba & grup nomina & grup adjektiva & label kelas \\
\hline
\end{tabular}

3) Di atas telaga itu terdapat kursi emas kerajaaan (Pangkur 10 bait ke-2)

\begin{tabular}{|c|c|c|c|}
\hline Di atas telaga itu & Terdapat & $\begin{array}{c}\text { kursi emas kera- } \\
\text { jaan }\end{array}$ & \\
\hline $\begin{array}{c}\text { Sirkumstan: lokasi: } \\
\text { tempat }\end{array}$ & $\begin{array}{c}\text { Proses: } \\
\text { wujud }\end{array}$ & Maujud & Label Fungsi \\
\hline grup adverbial & grup verba & grup nomina & Label Kelas \\
\hline
\end{tabular}

\section{Dominasi Proses Transitivitas TSMY}

Berdasarkan pembahasan analisis klausa tipe proses, pada TSMY terdapat enam proses yang digunakan, yaitu proses material, mental, relasional, verbal, tingkah laku, dan wujud. Dari enam proses tersebut, tipe proses yang dominan digunakan adalah proses material. Dari 352 klausa dalam TSMY, proses material memperoleh jumlah tertinggi, yakni berjumlah 127 atau $36.10 \%$. Tingginya penggunaan proses material dalam TSMY dapat diinterpretasikan bahwa teks TSMY banyak melibatkan aktivitas fisik. Pengarang ingin menunjukkan kepada pembaca bahwa aktivitas pemerintahan yang menyangkut aktivitas fisik begitu padat. Jika dilihat dari partisipan I yang mengikat proses material sebagian besar diperankan oleh pelaku raja, para pembesar kerajaan, dan mereka sebagai kata ganti untuk rakyat. Ini artinya pengarang ingin menyampaikan kepada pembaca bahwa roda pemerintahan tidak hanya dikuasai oleh segelintir orang saja tetapi terjadi kerja sama yang baik antara semua unsur. Dengan kata lain, raja dalam mejalankan roda pemerintahan tidak bersifat otoriter.

Peringkat kedua ditempati oleh proses verbal dengan jumlah 74 atau 21.02\%. Proses ini merupakan proses yang menunjukkan aktivitas yang menyangkut informasi. Hal ini dapat interpretasikan bahwa dalam teks TSMY ketika terjadi proses material atau aktivitas fisik maupun mental selalu didahului dengan informasi dan dialog 
antarsemua elemen yang ada sehingga roda pemerintahan berjalan dengan baik.

Peringkat ketiga didominasi oleh proses mental yang berjumlah 56 atau $15.90 \%$. Pemakaian proses mental dalam TSMY dapat bermakna bahwa dalam pencipta teks, pengarang banyak menggunakan kata-kata yang menyangkut pikiran, indera, dan perasaan untuk pelibat teks. Pelibat teks pada TSMY secara umum adalah keluarga kalangan istana yang berkaitan dengan aktivitas pemerintahan sehingga dapat dimengerti bahwa aktivitas yang dilakukan memerlukan kemampuan kognitif dalam berpikir, perenungan, pertimbangan, dan pengambilan keputusan.

Proses wujud menempati peringkat keempat dalam TSMY. Dari 352 klausa ditemukan sebanyak 38 atau 10.79\%. Kemunculan angka 10,79 \% menunjukkan pengarang tidak banyak memaparkan tentang keberadaan suatu tempat, kejadian, dan sarana prasarana. Namun demikian pemaparan pengalaman tentang keberadaan suatu tempat, kejadian, sarana dan prasarana yang ada pada lingkungan istana kepada pembaca sangat penting agar pembaca lebih cepat memahami cerita.

Pringkat kelima ditempati oleh proses relasional. Dari 352 klausa ditemukan sebanyak 34 atau 9.96\%. Hal ini menunjukkan bahwa pemakai bahasa dalam menulis TSMY berusaha menggunakan kata-kata yang bersifat definisi, menjelaskan, atau memaparkan seperti kata adalah, yaitu, dan menjadi.

Peringkat keenam adalah proses tingkah laku. Proses ini paling sedikit digunakan dalam TSMY, yaitu sebanyak 23 atau $6.53 \%$. Hal ini dapat dipahami bahwa semua aktivitas yang terjadi di dalam dan di luar istana harus berjalan sesuai dengan perintah, petunjuk, dan persetujuan kalangan istana.

Jumlah dan persentase penggunaan proses pada TSMY terlihat pada tabel berikut.

\begin{tabular}{|c|l|c|c|}
\hline No & Jenis Proses & Jumlah & \% \\
\hline 1 & Material & 127 & 36.10 \\
\hline 2 & Relasional & 34 & 9.66 \\
\hline 3 & Mental & 56 & 15.90 \\
\hline 4 & Verbal & 74 & 21.02 \\
\hline 5 & Wujud & 38 & 10.79 \\
\hline 6 & Tingkah Laku & 23 & 6.53 \\
\hline \multicolumn{2}{|c|}{ Jumlah } & $\mathbf{3 5 2}$ & $\mathbf{1 0 0}$ \\
\hline
\end{tabular}

Partisipan merupakan sesuatu yang dapat diikat oleh proses. Proses dapat dikaitkan sebagai inti atau pusat yang menarik unsur lain, termasuk partisipan. Karena proses merupakan inti, maka proses sangat menentukan jumlah partisipan yang dapat diikat dalam suatu proses. Dengan sifatnya yang demikian, proses digunakan sebagai dasar 
pelabelan partisipan dalam klausa sehingga muncul partisipan I dan II. Yang dimaksud dengan Partisipan I adalah Partisipan yang melakukan atau melaksanakan aktivitas atau Proses dan Partisipan II adalah Partisipan yang kepadanya aktivitas atau Proses ditujukan (Saragih, 2013:70).
Partisipan dalam penelitian ini dikelompokkan menjadi tiga, yaitu partisipan I, partisipan II, dan partisipan lain. Jumlah dan persentase kemunculan ketiga partisipan tersebut dalam TSMY, terlihat pada tabel-tabel.

\begin{tabular}{|c|c|c|c|}
\hline No & Jenis Partisipan I & $\begin{array}{c}\text { Jumla } \\
\mathrm{h}\end{array}$ & $\%$ \\
\hline 1 & Pelaku & 111 & 33.43 \\
\hline 2 & Pengindra & 55 & 16.57 \\
\hline 3 & Identifikasi bentuk/tanda & 14 & 4.22 \\
\hline 4 & Identifikasi penyandang & 8 & 2.41 \\
\hline 5 & Identifikasi kepemilikan & 11 & 3.31 \\
\hline 6 & Petingkah laku & 20 & 6.02 \\
\hline 7 & Pembicara & 77 & 23.20 \\
\hline \multirow[t]{2}{*}{8} & Maujud & 36 & 10.84 \\
\hline & Jumlah & 332 & $100 \%$ \\
\hline No & Jenis Partisipan II & $\begin{array}{c}\text { Jumla } \\
\mathrm{h}\end{array}$ & $\%$ \\
\hline 1 & Gol & 84 & 38.36 \\
\hline 2 & Penomenon & 42 & 19.18 \\
\hline 3 & Nilai & 13 & 5.94 \\
\hline 4 & Atribut & 8 & 3.65 \\
\hline 5 & Milik & 12 & 5.48 \\
\hline \multirow[t]{2}{*}{6} & Perkataan & 60 & 27.39 \\
\hline & Jumlah & 219 & $100 \%$ \\
\hline No & Jenis Partisipan Lain & $\begin{array}{c}\text { Jumla } \\
\mathrm{h}\end{array}$ & $\%$ \\
\hline 1 & Resipen & 5 & 23.81 \\
\hline 2 & Klien & 1 & 4.76 \\
\hline \multirow[t]{2}{*}{3} & Penerima & 15 & 71.43 \\
\hline & Jumlah & 21 & $100 \%$ \\
\hline
\end{tabular}

Dari tabel-tabel di atas jelas terlihat bahwa urutan dominasi proses sesuai dengan urutan dominasi partisipan I dan II, yaitu dimulai dari pelaku, pembicara, pengindra, maujud, tingkah laku, tanda, kepemilikan, dan penyandang. Demikian juga dengan partisipan II, secara berurut dari gol, perkataan, phenomenon, nilai, milik, dan atribut.

Sirkumstan merupakan lingkungan, si- 
fat, atau lokasi tempat berlangsungnya suatu proses. Sirkumstan berada di luar jangkauan proses. Oleh karena itu, sirkumstan berlaku dalam semua jenis proses. Sirkumstan setara dengan keterangan yang biasanya digunakan dalam tatabahasa tradisional (Saragih, 2006:38, 2013:17). Jadi, sirkum- stan berlaku untuk semua jenis proses, tetapi tidak semua proses diikuti sirkumstan karena sirkumstan berada di luar jangkauan proses. Jumlah dan persentase kemunculan sirkumstan dalam TSMY terpapar pada tabel berikut.

\begin{tabular}{|c|l|c|c|}
\hline No & \multicolumn{1}{|c|}{ Jenis Partisipan I } & $\begin{array}{c}\text { Jumla } \\
\mathrm{h}\end{array}$ & $\%$ \\
\hline 1 & Sirkumstan Rentang & 12 & 5.77 \\
\hline 2 & Sirkumstan Lokasi & 93 & 44.71 \\
\hline 3 & Sirkumstan Sebab & 9 & 4.33 \\
\hline 4 & Sirkumstan Lingkungan & 19 & 9.13 \\
\hline 5 & Sirkumstan Penyerta & 6 & 2.88 \\
\hline 6 & Sirkumstan Peran & 2 & 0.96 \\
\hline 7 & Sirkumstan Masalah & 9 & 4.33 \\
\hline 8 & Sirkumstan Pandangan & 2 & 0.96 \\
\hline 9 & Sirkumstan Cara & 42 & 20.19 \\
\hline 10 & Sirkumstan Kualitas & 14 & 6.73 \\
\hline & Jumlah & $\mathbf{2 0 8}$ & $\mathbf{1 0 0 \%}$ \\
\hline
\end{tabular}

\section{Kontribusi Hasil Kajian TSMY Ter- hadap Materi Pembelajaran Bahasa In- donesia Berbasis Teks Di SMP}

Hasil analisis terhadap klausa-klausa yang ada di dalam TSMY menunjukkan adanya beberapa hal yang sangat bermanfaat bagi pengembangan materi pembelajaran wacana berbasis teks di SMP, yaitu:

1) Hasil kajian ini dapat memberikan sumbangan bagi pengembangan materi pembelajaran yang terkait dengan aspekaspek kebahasaan, seperi kohesi dan koherensi, diksi/pilihan kata, dan lain-lain.

2) Hasil kajian ini dapat memberikan kontribusi bagi pengembangan materi pembelajaran bahasa berbasis teks yang berkaitan dengan grup kata, seperti nomina, verba, adverbial, pronominal, konjungsi, dan lain-lain.

3) Hasil kajian ini dapat memberikan kontribusi terhadap pengembangan materi pembelajaran berbasis teks yang berkaitan dengan struktur, dan unsurunsur yang membangun struktur tiaptiapteks.

4) Hasil kajian ini memberikan sumbangan bagi pengembangan materi pembelajaran berbasis teks terutama mengenai jenisjenis teks, seperti teks narasi,deskripsi, dan lain-lain. 


\section{SIMPULAN}

Hasil analisis data dan pembahasan terhadap TSMY dengan menggunakan teori LFS menyimpulkan tigal hal sebagai temuan dalam penelitian ini yaitu:

1. Tipe proses transitivitas yang terdapat dalam teks terjemahan TSMY meliputi enam jenis proses, yaitu proses material, mental, tingkah laku, relasional, verbal, dan proses ekstensial. Sirkumstan yang terdapat dalam TSMY meliputi sepuluh sirkumstan, yaitu sirkumstan rentang, lokasi, sebab, lingkungan, penyerta, peran, masalah, pandangan, cara, dan sirkumstan kualitas;

2. Tipe proses transitivitas yang mendominasi dalam teks terjemahan TSMY adalah penggunaan proses material dengan jumlah 127 atau $36,10 \%$. Hal ini dapat diinterpretasikan bahwa pemakai bahasa (pencipta teks) pada TSMY lebih condong menggunakan katakata yang mengisyaratkan adanya tindakan, kegiatan, dan aktivitas fisik pelibat teks (partisipan). Jika dilihat dari partisipan I yang mengikat proses material sebagian besar diperankan oleh pelaku raja, para pembesar kerajaan, dan mereka sebagai kata ganti untuk rakyat, pengarang ingin menyampaikan bahwa roda pemerintahan tidak hanya dikuasai oleh segelintir orang saja tetapi terjadi kerja sama yang baik antara semua unsur. Selain proses material, tipe proses yang dominan digunakan TSMY adalah proses verbal. Dominannya proses verbal dalam TSMY menunjukkan bahwa dalam melaksanakan aktivitas baik fisik maupun mental selalu didahului dengan informasi dan dialog antarsemua elemen yang ada sehingga roda pemerintahan berjalan dengan baik;

3. Kontribusi hasil penelitian terhadap teks terjemahan TSMY pada materi pembelajaran bahasa Indonesia berbasis teks di SMP adalah hasil penelitian ini dapat digunakan sebagai bahan ajar terutama yang terkait dengan teks.

\section{UCAPAN TERIMA KASIH}

Penulis mengucapkan terima kasih kepada Mitra Bebestari atas kritik dan masukan yang membangun untuk perbaikan artikel ini.

\section{DAFTAR PUSTAKA}

Eggins, Suzanne. 2004. An Introducingto Systemic Functional Linguistics. London: Continuum.

Gee, James Paul.2011.An Introducing to Discourse.New York: Routledge.

Halliday,M.A.K.\& Ruqaiya Hasan.1992.Bahasa,Konteks, danTeks:A spek - aspek BahasadalamPandanganSemiotikSosial.Diterjemahkanoleh AsruddinBaroriTou \&M.Ramlan dari judulLanguage, Context,and Text:Aspectof Language inaSocial-Semiotic Perspective.Yogyakarta: Gadjah MadaUniversityPress.

Imtihani, Najih. 2010. Genre Analysisin The Frame of Systemic Functional Linguistics.Jurnal HumanioraVol. 22, No. 1: 8693.

Kridalaksaa,Harimurti.2009.KamusLinguistikE disiIV.Jakarta:Gramedia PustakaUtama.

Mahsun. 2007. Edisi Revisi: Metode Penelitian Bahasa: Tahapan Strategi, Metode, dan Tekniknya. Jakarta: Raja GrafindoPersada.

Mahsun. 2013.Teks dalam Pembelajaran Bahasa Indonesia: Kurikulum 2013. Jakarta: Raja 
GrafindoPersada.

Saragih, A. 2006. Bahasa dalam KonteksSosial: Pendekatan Linguistik FungsionalSistem$i k$ terhadap TatabahasadanWacana. Medan: PascasarjanaUnimed Press.
Saragih, A. 2013. Semiotika Bahasa: Tanda, Penanda, dan Petanda Dalam Bahasa. Medan: Pascasarjana Unimed Press.

Sinar, Tengku Sinar. 2012. Teori \& Analisis Wacana: Pendekatan Sistemik Fungsional. Medan: CV MITRA Medan. 